STUDIA Z PRAWA WYZNANIOWEGO

Tom $22-2019$

DOI: https://doi.org/10.31743/spw.5479

\title{
ULGI PODATKOWE Z TYTUŁU DAROWIZN NA KOŚCIELNĄ DZIAŁALNOŚĆ CHARYTATYWNO-OPIEKUŃCZĄ
}

\section{Streszczenie}

Związki wyznaniowe w Polsce mogą być finansowane m.in. poprzez przekazywanie na ich rzecz darowizn. Darczyńca z tytułu dokonania darowizny może skorzystać z ulgi podatkowej. W sposób szczególny darczyńca może skorzystać z ulgi podatkowej z tytułu dokonania darowizny na kościelną działalność charytatywno-opiekuńczą prowadzoną przez kościelne osoby prawne. Podstawę normatywną tej ulgi podatkowej stanowią właściwe przepisy ustaw, które regulują sytuację prawną poszczególnych związków wyznaniowych, a nie ustawy podatkowe. Jednak przepisy wskazanych ustaw możliwość skorzystania z tej ulgi podatkowej uzależniają od spełnienia kilku warunków. Kościelna osoba prawna, na rzecz której dokonano darowizny, powinna wystawić darczyńcy pokwitowanie odbioru darowanej kwoty oraz w ciągu dwóch lat od jej uzyskania jest zobowiązana złożyć sprawozdanie z przeznaczenia wskazanej kwoty na działalność charytatywno-opiekuńczą. Ponadto, zgodnie z przepisami podatkowymi potwierdzeniem wysokości darowanej kwoty powinien być dowód wpłaty darowizny na rachunek bankowy osoby obdarowanej. W praktyce spełnienie wskazanych warunków wywołuje wiele trudności. Świadczy o tym bogate orzecznictwo Naczelnego Sądu Administracyjnego, zwłaszcza dotyczące zagadnienia sprawozdania z przeznaczenia darowizny na działalność charytatywno-opiekuńczą kościelnej osoby prawnej.

Naczelny Sąd Administracyjny w swoim orzecznictwie doprecyzowuje pojęcie sprawozdania z przeznaczenia darowizny na działalność charytatywno-opiekuńczą kościelnej osoby prawnej. Jednak, jak pokazuje praktyka, wyjaśnienia te są nadal niewystarczające.

* Dr, Katedra Prawa Wyznaniowego, Wydział Prawa, Prawa Kanonicznego i Administracji, Katolicki Uniwersytet Lubelski Jana Pawła II, Al. Racławickie 14, 20-950 Lublin, e-mail: abrama@kul.pl. ORCID 0000-0002-1601-6969. 
Słowa kluczowe: ulga podatkowa; darowizna; działalność charytatywno-opiekuńcza; Naczelny Sąd Administracyjny; sprawozdanie; kościelna osoba prawna; orzecznictwo NSA

$* * * * *$

\section{WPROWADZENIE}

Związki wyznaniowe w Polsce są finansowane m.in. poprzez przekazywane przez wiernych darowizny ${ }^{1}$. Taka forma finansowania jest powszechnie spotykana na całym świecie ${ }^{2}$. Trzeba zaznaczyć, że z prawem do otrzymywania darowizn przez związki wyznaniowe, łączy się również prawo darczyńców do korzystania z ulg podatkowych z tytułu dokonania wskazanego przysporzenia. Podobne rozwiązania prawne funkcjonują $\mathrm{w}$ systemach prawnych innych państw ${ }^{3}$. Związki wyznaniowe w Polsce prawo do otrzymywania darowizn mają unormowane w ustawie z dnia 17 maja 1989 r. o gwarancjach wolności sumienia i wyznania ${ }^{4}$. W art. 19 ust. 1 i ust. 2 pkt 8 tej ustawy wskazano, że związki wyznaniowe na zasadzie równouprawnienia mogą m.in. otrzymywać darowizny od osób fizycznych i prawnych. W Polsce związki wyznaniowe mogą otrzymywać darowizny na cele kultu religijnego ${ }^{5}$. Trzeba pamiętać, że odnoszące się do tej darowizny przepisy wprowadzają górne limity możliwości

1 Zob. Ners 2000, 138; Walencik 2004, 168-169; Stanisławski 2009, 329; Stanisławski 2003, 175-181; Pieron 2011, 148-152.

2 Dobrowolne darowizny wiernych są głównym źródłem finansowania związków wyznaniowych we Francji (oprócz trzech wschodnich departamentów, gdzie obowiązuje Konkordat z 1801 r.), Holandii, Zjednoczonym Królestwie, Portugalii oraz Irlandii. Schanda 2003, 210-211.

3 Zob. Misztal, Stanisz 2009, 351-353; Stanisz 2009, 27-28.

4 Tekst jedn. Dz. U. z 2017 r., poz. 1153.

5 Właściwe podstawy prawne dotyczące takiej darowizny są określone w art. 26 ust. 1 pkt 9 lit. b ustawy z dnia 26 lipca 1991 r. o podatku dochodowym od osób fizycznych (tekst jedn. Dz. U. z 2018 r., poz. 200 z późn. zm.) i w art. 18 ust. 1 pkt 7 ustawy z dnia 15 lutego 1992 r. o podatku dochodowym od osób prawnych (tekst jedn. Dz. U. z 2017 r., poz. 2343 z późn. zm.). Związki wyznaniowe i ich osoby prawne mogą również uzyskiwać darowizny na podstawie przepisów ustawy z dnia 24 kwietnia 2003 r. o działal- 
odliczenia kwot od podstawy opodatkowania podatkiem dochodowym od osób fizycznych i osób prawnych z tytułu dokonanej darowizny. Oznacza to, że darczyńcy z tytułu dokonania darowizny mogą skorzystać z ulgi podatkowej do określonego limitu'

Polski prawodawca wprowadził ponadto możliwość przekazywania darowizn na kościelną działalność charytatywno-opiekuńczą prowadzoną przez kościelne osoby prawne7. Podstawę normatywną dokonywania tej darowizny stanowią właściwe przepisy ustaw, które regulują sytuację prawną poszczególnych związków wyznaniowych ${ }^{8}$. Przepisy tych ustaw

ności pożytku publicznego i o wolontariacie (tekst jedn. Dz. U. z 2019 r., poz. 688). Zob. Stanisz 2017, 124; Stanisz 2012, 166; Koredczuk 2013, 268; Maruszak 2011, 162-163.

6 Górny limit odliczeń od podstawy opodatkowania podatkiem dochodowym w stosunku do osób prawnych wynosi $10 \%$ dochodu, natomiast w stosunku do osób fizycznych limit ten wynosi 6\% dochodu. Stanisz 2011a, 242; Stanisławski 2004, 212-213; Stanisławski 2011, 101-102; Walencik 2012, 99.

7 Należy tu wskazać również możliwość przekazania 1\% podatku dochodowego na rzecz organizacji pożytku publicznego. Status takiej organizacji może uzyskać również kościelna osoba prawna po spełnieniu wymagań określonych w art. 20-21 ustawy o działalności pożytku publicznego i wolontariacie. Zob. Walencik 2009a, 9-25; Walencik 2009b, 311-327.

8 Zob.: art. 55 ust. 7 ustawy z dnia 17 maja 1989 r. o stosunku Państwa do Katolickiego w Rzeczypospolitej Polskiej (tekst jedn. Dz. U. z 2019 r., poz. 1347); art. 40 ust. 7 ustawy z dnia 4 lipca 1991 r. o stosunku Państwa do Polskiego Autokefalicznego Kościoła Prawosławnego w Rzeczypospolitej Polskiej (tekst jedn. Dz. U. z 2014 r., poz. 1726); art. 34 ust. 2 ustawy z dnia 13 maja 1994 r. o stosunku Państwa do Kościoła Ewangelicko-Augsburskiego w Rzeczypospolitej Polskiej (tekst jedn. Dz. U. z 2015 r., poz. 43); art. 19 ust. 2 ustawy z dnia 13 maja 1994 r. o stosunku Państwa do Kościoła Ewangelicko-Reformowanego w Rzeczypospolitej Polskiej (tekst jedn. Dz. U. z 2015 r., poz. 483); art. 27 ust. 5 ustawy z dnia 30 czerwca 1995 r. o stosunku Państwa do Kościoła Polskokatolickiego w Rzeczypospolitej Polskiej (tekst jedn. Dz. U. z 2014 r., poz. 1599); art. 28 ust. 5 ustawy z dnia 30 czerwca 1995 r. o stosunku Państwa do Kościoła Adwentystów Dnia Siódmego w Rzeczypospolitej Polskiej (tekst jedn. Dz. U. z 2014 r., poz. 1889); art. 33 ust. 5 ustawy z dnia 30 czerwca 1995 r. o stosunku Państwa do Kościoła Chrześcijan Baptystów w Rzeczypospolitej Polskiej (tekst jedn. Dz. U. z 2015 r., poz. 169); art. 29 ust. 5 ustawy z dnia 30 czerwca 1995 r. o stosunku Państwa do Kościoła Ewangelicko-Metodystycznego w Rzeczypospolitej Polskiej (tekst jedn. Dz. U. z 2014 r., poz. 1712); art. 26 ust. 5 ustawy z dnia 20 lutego 1997 r. o stosunku Państwa do Kościoła Starokatolickiego Mariawitów w Rzeczypospolitej Polskiej (tekst jedn. Dz. U. z 2015 r., poz. 14); art. 29 ust. 5 ustawy z dnia 20 lutego 1997 r. o stosunku Państwa do Kościoła Zielonoświątkowego w Rzeczypospolitej Polskiej (tekst jedn. Dz. U. z 2015 r., poz. 13); art. 24 ust. 5 ustawy z dnia 20 lutego 1997 r. o stosunku Państwa do Koś- 
regulują zasady dokonywania darowizn na kościelną działalność charytatywno-opiekuńczą, wskazując, że darczyńcy mogą skorzystać z ulgi podatkowej polegającej na możliwości odliczenia kwoty dokonanej darowizny od podstawy opodatkowania podatkiem dochodowym od osób fizycznych. Należy podkreślić, że wskazane przepisy nie zawierają żadnych limitów dopuszczalnych odliczeń ${ }^{9}$. Jednak przepisy wskazanych ustaw możliwość skorzystania $\mathrm{z}$ tej ulgi podatkowej uzależniają od spełnienia kilku warunków. Ponadto, zgodnie z przepisami ustawy o podatku dochodowym od osób fizycznych potwierdzeniem wysokości darowanej kwoty powinien być dowód wpłaty wskazanej darowizny na rachunek bankowy osoby obdarowanej $^{10}$. W praktyce spełnienie wszystkich warunków wywołuje wiele trudności, o czy świadczy o tym bogate orzecznictwo Naczelnego Sądu Administracyjnego. Uzasadnia to podjęcie rozważań dotyczących zagadnienia prawa do skorzystania z ulgi podatkowej z tytułu darowizn na kościelną działalność charytatywno-opiekuńczą. Z uwagi na złożoność i skomplikowaną specyfikę tego zagadnienia warunek konieczności wpłaty darowizny na rachunek bankowy osoby obdarowanej nie będzie szerzej podjęty w tym opracowaniu ${ }^{11}$. Warunek ten, od którego spełnienia uzależnia się możliwość skorzystania z ulgi podatkowej, wymaga szerokiego i kompleksowego omówienia. Niniejsze opracowanie będzie miało na celu przede wszystkim dokonanie przeglądu i analizy orzecznictwa NSA dotyczącego zagadnienia ulgi podatkowej z tytułu darowizn na kościelną działalność charytatywno-opiekuńczą. Wskazane zostaną podstawowe warunki konieczne do skorzystania z ulgi z tytułu darowizny na kościelną działalność charytatywno-opiekuńczą. W szczególności rozważania zastaną poświęcone zagadnieniu sprawozdania z przeznaczenia wskazanej kwoty na działalność charytatywno-opiekuńczą jako koniecznemu warunkowi do skorzystania z ulgi podatkowej z tytułu dokonania darowizny na kościelną działalność charytatywno-opiekuńczą.

cioła Katolickiego Mariawitów w Rzeczypospolitej Polskiej (tekst jedn. Dz. U. z 2015 r., poz. 44).

9 Walencik 2012, 100; Maruszak 2011, 165-166.

10 Stanisz 2011a, 243-244; Stanisławski 2004, 217; Walencik 2010, 269-275; Stanisławski 2009, 336-337.

11 Zob. Waniek 2018, 209-220. 


\section{PODSTAWOWE WARUNKI KONIECZNE DO SKORZYSTANIA Z ULGI Z TYTUŁU DAROWIZNY NA KOŚCIELNĄ DZIAŁALNOŚĆ CHARYTATYWNO-OPIEKUŃCZĄ W ORZECZNICTWIE NSA}

Analizę zasad określających prawo do skorzystania z ulgi z tytułu dokonania darowizny na kościelną działalność charytatywno-opiekuńczą należy rozpocząć od niezwykle istotnej uchwały Izby Finansowej Naczelnego Sądu Administracyjnego z dnia 14 marca 2005 r. (FPS 5/04), która miała za zadanie wyjaśnić wątpliwości co do darowizn dokonywanych przez osoby fizyczne na kościelną działalność charytatywno-opiekuńczą ${ }^{12}$. Stwierdzono tam, że darowizna taka stosownie do art. 55 ust. 7 ustawy z dnia 17 maja 1989 r. o stosunku Państwa do Kościoła Katolickiego w RP oraz art. 40 ust. 7 ustawy z dnia 4 lipca 1991 r. o stosunku Państwa do Polskiego Autokefalicznego Kościoła Prawosławnego jest wyłączona z podstawy opodatkowania darczyńcy podatkiem dochodowym od osób fizycznych. Zgodnie z interpretacją NSA wskazanych przepisów należy je rozumieć jako szczególne wobec przepisów ustawy o podatku dochodowym od osób fizycznych ${ }^{13}$. Zatem zgodnie z zasadą lex specialis derogat legi generali przepisy ustaw o stosunku Państwa do poszczególnych związków wyznaniowych mają w tym przypadku pierwszeństwo wobec przepisów ustawy o podatku dochodowym od osób fizycznych. Nie ma tu konieczności spełniania przesłanek przewidzianych w art. 26 ust. 1 ustawy o podatku dochodowym od osób fizycznych, a wyłącznym warunkiem jest spełnienie przesłanek, o których mowa we wskazanych przepisach ustawy o stosunku Państwa do Kościoła Katolickiego oraz ustawy o stosunku Państwa do Polskiego Autokefalicznego Kościoła Prawosławnego, mianowicie: „,[d]arowizny na kościelną działalność charytatywno-opiekuńczą są wyłączone z podstawy opodatkowania darczyńców podatkiem dochodowym i podatkiem wyrównawczym, jeżeli kościelna osoba prawna przedstawi darczyńcy pokwitowanie odbioru oraz - w okresie dwóch lat od dnia przekazania darowizny - sprawozdanie o przeznaczeniu jej na tę działalność. W odniesieniu do darowizn na inne cele mają zastosowanie ogólne

12 Walencik 2007, 252; Walencik 2010, 264-265. Por. Pietrzak 2010, 289-290.

13 Stanisławski 2004, 216-217; Rakoczy 2008, 336-340; Stanisławski 2001, 82-86; Czuryk 2013, 243. 
przepisy podatkowe". Trzeba dodać, że analogicznie należy odnieść powyższe rozważania do właściwych przepisów ustaw regulujących sytuację prawną poszczególnych związków wyznaniowych w zakresie możliwości skorzystania z ulgi podatkowej z tytułu dokonania darowizny na kościelną działalność charytatywno-opiekuńczą. Podobnie kolejne rozważania dotyczące orzecznictwa Naczelnego Sądu Administracyjnego, mimo że przede wszystkim opierają się na orzeczeniach dotyczących art. 55 ust. 7 ustawy o stosunku Państwa do Kościoła Katolickiego w RP, należy analogicznie odnieść do właściwych przepisów ustaw regulujących sytuację prawną pozostałych związków wyznaniowych ${ }^{14}$.

14 Zob. przypis 8. Nie we wszystkich aktach regulujących sytuację prawną poszczególnych związków wyznaniowych zawarte są przepisy gwarantujące możliwość skorzystania z ulgi podatkowej przez darczyńcę dokonującego przysporzenia na rzecz kościelnych osób prawnych w celu realizacji ich działalności charytatywno-opiekuńczej. Takich przepisów nie ma w unormowaniach dotyczących Wschodniego Kościoła Staroobrzędowego, Karaimskiego Związku Religijnego, Muzułmańskiego Związku Religijnego oraz Gmin Wyznaniowych Żydowskich (zob. Zieliński 2012, 173). Ponadto przepisy ustaw o stosunku Państwa do Kościoła Katolickiego i Polskiego Autokefalicznego Kościoła Prawosławnego nie wprowadzają ograniczenia w postaci możliwości skorzystania ze wskazanej ulgi podatkowej jedynie przez osoby fizyczne. Takie ograniczenia są widoczne natomiast w przepisach pozostałych ustaw regulujących w sposób indywidualny status prawny poszczególnych związków wyznaniowych (Abramowicz 2018, 292-293). Osobami korzystającymi z omawianej ulgi podatkowej z tytułu dokonania darowizny na wskazany cel, na rzecz kościelnych osób prawnych Kościoła Katolickiego i Polskiego Autokefalicznego Kościoła Prawosławnego mogą być tylko osoby fizyczne (Pietrzak 2010, 289; Borecki 2007, 146-147; Borecki 2015, 180-181). Taki wniosek nasuwa nowelizacja prawa podatkowego (ustawa z dnia 16 grudnia 1993 r. o zmianie niektórych ustaw regulujących zasady opodatkowania oraz niektórych innych ustaw, Dz. U. z 1993 r. Nr 134, poz. 646), która z dniem 1 stycznia 1992 r. uchyliła ustawę z dnia 28 lipca 1983 r. o podatku wyrównawczym (Dz. U. z 1983 r. Nr 42, poz. 188 z późn. zm.). Oznacza to, że przepis art. 55 ust. 7 ustawy o stosunku Państwa do Kościoła Katolickiego oraz przepis art. 40 ust. 7 ustawy o stosunku Państwa do Polskiego Autokefalicznego Kościoła Prawosławnego w zakresie podatku wyrównawczego stały się bezprzedmiotowe. Za taką interpretacją przemawia również zasada równouprawnienia związków wyznaniowych uregulowana w art. 25 ust. 1 Konstytucji RP (Dz. U. z 1997 r. Nr 78, poz. 483 z poźn. zm.). Kolejne uchwalone ustawy regulujące stosunek Państwa do poszczególnych związków wyznaniowych ograniczają podmiotowo zakres prawa do skorzystania ze wskazanej ulgi podatkowej jedynie do osób fizycznych i nie wprowadzają takiego uprawnienia w stosunku do osób prawnych (zob. rozważania na ten temat w uchwale podjętej przez cały 
Zgodnie z orzecznictwem NSA warunkiem koniecznym do skorzystania ze wskazanej ulgi jest spełnienie łącznie dwóch przesłanek. Darowizna na kościelną działalność charytatywno-opiekuńczą wyłączona jest z podstawy opodatkowania darczyńcy, jeżeli kościelna osoba prawna przedstawi darczyńcy pokwitowanie odbioru oraz w okresie dwóch lat od dnia przekazania darowizny sprawozdanie o przeznaczeniu tej darowizny na taką działalnośćc ${ }^{15}$. Realizacja ulgi podatkowej określonej we właściwych przepisach ustaw regulujących stosunek Państwa do poszczególnych związków wyznaniowych nie następuje z mocy prawa, jedynie przez fakt zawarcia i wykonania umowy darowizny na cel wskazany w przepisie, ale po spełnieniu wszystkich określonych $\mathrm{w}$ nim przesłanek ${ }^{16}$.

Cytowany przepis jest zdaniem NSA jasny w swej treści. Zatem z chwilą dokonania odliczeń podatnik musi dysponować pokwitowaniem odbioru darowizny, natomiast sprawozdaniem dotyczącym jej przeznaczenia, przedstawionym przez kościelną osobę prawną - najpóźniej po upływie dwóch lat od dnia przekazania darowizny. Sprawozdanie, o którym mowa w tych przepisach, oraz pokwitowanie powinno pochodzić od tej kościelnej osoby prawnej, która została obdarowana ${ }^{17}$. Niespełnienie wskazanych warunków skutkuje brakiem podstaw do skorzystania z prawa do ulgi z ty-

skład Izby Finansowej NSA z dnia 14 marca 2005 r. FPS 5/04, ONSAiWSA z 2005 r., nr 3, poz. 49 oraz Stanisz 2011a, 243).

15 Wyrok NSA z dnia 31 maja 2005 r. FSK 1808/04, LEX nr 154522; Wyrok NSA z dnia 9 czerwca 2005 r. FSK 1807/04, LEX nr 173058; Wyrok NSA z dnia 7 lipca 2005 r. FSK 1995/04, LEX nr 173231; Wyrok NSA z dnia 23 marca 2006 r. II FSK 1405/05, LEX nr 261089; Wyrok NSA z dnia 13 kwietnia 2007 r. II FSK 556/06, LEX nr 927068; Wyrok NSA z dnia 26 października 2007 r. II FSK 1203/06 LEX nr 926621; Wyrok NSA z dnia 25 czerwca 2008 r. II FSK 664/07 LEX nr 485166; Wyrok NSA z dnia 11 lutego 2009 r. II FSK 1575/07, LEX nr 485961; Wyrok NSA z dnia 10 grudnia 2009 r. II FSK 1153/08, LEX nr 580680; Wyrok NSA z dnia 8 listopada 2011 r. II FSK 891/10, LEX nr 989141; Wyrok NSA z dnia 26 czerwca 2013 r. II FSK 2133/11, LEX nr 1557838; Wyrok NSA z dnia 6 września 2013 r. II FSK 2607/11, LEX nr 1375614; Wyrok NSA z dnia 14 lutego 2014 r. II FSK 397/12, LEX nr 1450269; Wyrok NSA z dnia 12 lipca 2016 r. II FSK 1824/14, LEX nr 2101424; Wyrok NSA z dnia 9 sierpnia 2016 r. II FSK 2397/14, LEX nr 2116249; Wyrok NSA z dnia 25 października 2016 r. II FSK 2637/14, LEX nr 2174919.

16 Wyrok NSA z dnia 26 czerwca 2013 r. II FSK 2133/11, LEX nr 1557838; Wyrok NSA z dnia 12 lipca 2016 r. II FSK 1824/14, LEX nr 2101424; Wyrok NSA z dnia 25 października 2016 r. II FSK 2637/14, LEX nr 2174919.

17 Wyrok NSA z dnia 11 lutego 2009 r. II FSK 1575/07, LEX nr 485961. 
tułu dokonanej darowizny na kościelną działalność charytatywno-opiekuń$\mathrm{cza}^{18}$. W takim przypadku organ podatkowy wydaje decyzję określającą prawidłową wysokość zobowiązania podatkowego. Bezpodstawne skorzystanie z ulgi podatkowej może skutkować również powstaniem zaległości podatkowej, a jej następstwem mogą być odsetki za zwłokę ${ }^{19}$.

NSA w swoich orzeczeniach słusznie wskazuje, że celem i uzasadnieniem pozytywnego stymulowania przez prawodawcę darowizn na działalność charytatywno-opiekuńczą niewątpliwie jest i być powinno rzeczywiste prowadzenie i efektywna realizacja tej działalności, a nie tylko zamiary. Warunkiem korzystania $\mathrm{z}$ ulgi, zgodnie $\mathrm{z}$ analizowanymi przepisami nie są jedynie intencje darczyńcy, ale ich realizacja przez obdarowaną kościelną osobę prawną. Realizacja ta musi zostać opisana w sprawozdaniu i wskazywać faktyczne przeznaczenie darowizny na wskazany w przepisie cel. Ponadto niezgodne z rzeczywistym stanem rzeczy oświadczenie o wykorzystaniu darowizny na działalność charytatywno-opiekuńczą nie będzie prawnie znaczące dla realizacji ulgi podatkowej z tytułu dokonania darowizny na kościelną działalność charytatywno-opiekuńczą. Takie nieodpowiadające prawdzie oświadczenie, nawet nazwane sprawozdaniem, nie będzie dotyczyć i sprawozdawać przeznaczenia darowizny na cel uzasadniający ulgę podatkową ${ }^{20}$. W orzecznictwie wielokrotnie podkreślono, że sprawozdanie, by mogło być uznane za formalnie i materialnie poprawne, musi zawierać szczegółowe dane pozwalające ustalić, czy darowizna została faktycznie spożytkowana na cel określony ustawowo, a przedstawione w nim informacje muszą być weryfikowalne ${ }^{21}$. Jednak jak wskazuje

18 Wyrok NSA z dnia 12 lipca 2018 r. II FSK 1946/16, LEX nr 2538086.

19 Wyrok NSA z dnia 9 sierpnia 2016 r. II FSK 2049/14, LEX nr 2118972; Wyrok NSA z dnia 25 października 2016 r. II FSK 2637/14, LEX nr 2174919.

20 Wyrok NSA z dnia 23 marca 2006 r., sygn. akt II FSK 1405/05, LEX nr 261089; Wyrok NSA z dnia 25 października 2007 r. II FSK 1180/06, LEX nr 440475; Wyrok NSA z dnia 25 maja 2011 r. II FSK 67/10, LEX nr 846669; Wyrok NSA z dnia 16 grudnia 2011 r. II FSK 1195/10, LEX nr 1151283; Wyrok NSA z dnia 16 grudnia 2011 r. II FSK 1763/10, LEX nr 1112481; Wyrok NSA z dnia 26 czerwca 2013 r. II FSK 2133/11, LEX nr 1557838.

${ }^{21}$ Wyrok NSA z dnia 14 lutego 2007 r. II FSK 262/06, LEX nr 302863; Wyrok NSA z dnia 8 stycznia 2008 r. II FSK 1547/06, LEX nr 467823; Wyrok NSA z dnia 25 czerwca 2008 r. II FSK 663/07, LEX nr 472269; Wyrok NSA z dnia 25 czerwca 2008 r. II FSK 664/07, LEX nr 485166; Wyrok NSA z dnia 10 listopada 2017 r. II FSK 2906/15, LEX nr 2422973; Wyrok NSA z dnia 12 lipca 2018 r. II FSK 1946/16, LEX nr 2538086. 
na to wielość wydawanych orzeczeń przez NSA, wskazane wymogi nie są wystarczająco zrozumiałe.

\section{OKREŚLENIE POJĘCIA „SPRAWOZDANIE”}

Wielowątkowe w swojej treści rozważania można odnaleźć w bogatym orzecznictwie NSA na temat pojęcia sprawozdania o przeznaczeniu darowizny na kościelną działalność charytatywno-opiekuńczą. Należy zauważyć, że właściwe przepisy ustaw regulujących sytuację prawną poszczególnych związków wyznaniowych nie definiują pojęcia sprawozdania. Brak jest tam również doprecyzowania jego charakteru. Próby doprecyzowania tego pojęcia podejmowane są natomiast w orzecznictwie NSA, gdzie można odnaleźć wiele wskazówek dotyczących właściwego rozumienia tego pojęcia.

NSA zauważa, iż przepisy ustaw o stosunku Państwa do poszczególnych związków wyznaniowych nie wskazują, jakie wymogi powinno spełniać sprawozdanie, które jest jednym z dokumentów uprawniających do skorzystania $\mathrm{z}$ ulgi w postaci wyłączenia darowizny z podstawy opodatkowania. W szczególności przepis ten nie określa ani jego formy, ani stopnia jego szczegółowości. Wobec braku definicji legalnej pojęcia ,sprawozdanie" należy zdaniem NSA przy interpretacji tego przepisu sięgać do rozumienia słownikowego. Ponadto zgodnie z przekonującym stanowiskiem NSA pojęcie „sprawozdanie” nie może być interpretowane samodzielnie, a jedynie w połączeniu z określeniem ,sprawozdanie o przeznaczeniu na działalność charytatywno-opiekuńczą”. Interpretacja pojęcia „,sprawozdanie" w oderwaniu od pozostałej treści przepisu jest - zdaniem NSA - niedopuszczalna, bo prowadzi to do błędnych wniosków ${ }^{22}$.

NSA wielokrotnie podkreślał, że jedynie odwołanie się do słownikowego określenia pojęcia „sprawozdanie” zapewni realizację dyrektywy równości opodatkowania i pozostaje w zgodności z zasadami interpretacji prawa podatkowego. Za takim rozumieniem przepisów ustaw o stosunku Państwa do poszczególnych związków wyznaniowych przemawia rów-

22 Wyrok NSA z dnia 26 stycznia 2010 r. II FSK 545/09, LEX nr 596505; Wyrok NSA z dnia 31 sierpnia 2017 r. II FSK 2117/15, LEX nr 2344705. 
nież fakt, że ustawodawca wyznaczył aż dwuletni okres na sporządzenie sprawozdania, które ma określać rzeczywiste, efektywne wykorzystanie przeznaczonych na działalność charytatywno-opiekuńczą środków. Chodzi więc o sprawozdanie z czegoś, co już się zrealizowało w konkretnej formie, a nie o powiadomienie, nawet $\mathrm{w}$ formie sprawozdania, o niezrealizowanych intencjach ${ }^{23}$.

Zatem, zdaniem Naczelnego Sądu Administracyjnego, brak legalnej definicji pojęcia „sprawozdanie” nie stoi na przeszkodzie w ustaleniu treści, jaką powinno ono zawierać. Zarówno jego treść, jak i stopień szczegółowości zakreśla cel, w jakim winno być sporządzone sprawozdanie. Cel ten wywieść można $\mathrm{z}$ właściwych przepisów ustaw określających sytuację prawną poszczególnych związków wyznaniowych. Natomiast zgodnie z definicją zaczerpniętą ze Słownika Języka Polskiego „sprawozdanie" to przedstawienie przebiegu jakiejś działalności, opis wypadków, zdarzeń, relacja ${ }^{24}$. Kontekst, w jakim to słowo występuje w omawianym przepisie, wskazuje, że jego użycie byłoby pozbawione sensu, gdyby odnosić się miało do pojęcia ,przeznaczenie”. Sprawozdanie z przeznaczenia darowizny na cele wskazane w powołanym przepisie oznaczałoby relację z podjęcia decyzji o wykorzystaniu darowizny do realizacji tych celów. Oznaczałoby to sprawozdanie z planów, zamiarów czy też intencji. Dla uzyskania wiedzy o tych zdarzeniach nie jest wymagane otrzymanie sprawozdania o tych faktach, gdyż udzielenie informacji o nich możliwe jest w drodze zwykłego powiadomienia. Pojęcie „sprawozdanie” we wskazanym powyżej rozumieniu językowym wręcz nie pasuje do pojęcia ,,przeznaczenie", gdyż sprawozdanie jest relacją o faktach, które się wydarzyły. W znaczeniu językowym pojęcie „sprawozdanie” nie obejmuje swym zakresem procesów myślowych, do których zalicza się powzięcie decyzji o przeznaczeniu darowizny na określony cel lub planowania podjęcia takiej decyzji ${ }^{25}$. NSA zauważa także, że użycie w analizowanym przepisie słowa „sprawozdanie” oznaczającego przedstawienie przebiegu jakiejś

23 Wyrok NSA z dnia 4 stycznia 2007 r. II FSK 588/06, LEX nr 453235; Wyrok NSA z dnia 31 stycznia 2007 r. II FSK 199/06, LEX nr 291809.

24 Skorupka, Auderska, Łempicka 1968, 769.

25 Wyrok NSA z dnia 22 czerwca 2010 r. II FSK 364/09, LEX nr 643580; Wyrok NSA z dnia 25 czerwca 2008 r. II FSK 664/07, LEX nr 485166; Wyrok NSA z dnia 12 lipca 2018 r. II FSK 1946/16, LEX nr 2538086. 
działalności, opis wypadków, zdarzeń, relację, byłoby semantycznie całkowicie nieuzasadnione, gdyby odnosić się miało do niezrealizowanych planów, zamiarów czy też intencji, które dla uzyskania wiedzy o nich, nie wymagają sprawozdania, a tylko powiadomienia, zwykłego przekazania informacji ${ }^{26}$.

Zatem zgodnie z orzecznictwem NSA sprawozdanie, o którym mowa w tym przepisie, powinno obejmować dwa lata i przedstawiać przebieg działalności, wypadków, zdarzeń, relację. Poza tym informacje umieszczone w takim sprawozdaniu powinny być dokładne, konkretne, sprawdzalne, ujęte w taki sposób, aby można było zweryfikować, że darowizny w rzeczywistości zostały przeznaczone na kościelną działalność charytatywno-opiekuńczą ${ }^{27}$.

NSA podkreśla, że sprawozdanie ma opisywać szczegółowo proces spożytkowania kwoty uzyskanej darowizny. Ten szczegółowy proces ma mieć nie tylko przedmiotowy, ale i podmiotowy charakter. Zgodnie ze słownikową definicją „,szczegółowo” oznacza „,z dokładnym uwzględnieniem szczegółów, drobiazgowo, skrupulatnie"28. Sprawozdanie, zdaniem NSA nie będzie więc szczegółowe, drobiazgowe, skrupulatne wówczas, gdy ograniczy się tylko do opisu przedmiotowego. Zatem sprawozdanie, o którym jest mowa w przepisach ustaw określających sytuacje prawną poszczególnych związków wyznaniowych, powinno odzwierciedlać nie tylko to co, ale i komu przeznaczono w taki sposób, aby w toku postępowania podatkowego było możliwe dokładne zweryfikowanie spełnienia celu charytatywno-opiekuńczego zrealizowanego przez kościelne osoby praw-

26 Wyrok NSA z dnia 14 lutego 2007 r. II FSK 262/06, LEX nr 302863; Wyrok NSA z dnia 8 stycznia 2008 r. II FSK 1547/06, LEX nr 467823; Wyrok NSA z dnia 25 czerwca 2008 r. II FSK 663/07, LEX nr 472269; Wyrok NSA z dnia 25 czerwca 2008 r. II FSK 664/07, LEX nr 485166; Wyrok NSA z dnia 25 maja 2011 r. II FSK 67/10, LEX nr 846669; Wyrok NSA z dnia 10 listopada 2017 r. II FSK 2906/15, LEX nr 2422973; Wyrok NSA z dnia 12 lipca 2018 r. II FSK 1946/16, LEX nr 2538086.

27 Wyrok NSA z dnia 23 marca 2006 r. II FSK 1405/05, LEX nr 261089; Wyrok NSA z dnia 10 grudnia 2013 r. II FSK 141/12, LEX nr 1529938; Wyrok NSA z dnia 10 listopada 2017 r. II FSK 2906/15, LEX nr 2422973; Wyrok NSA z dnia 28 listopada 2017 r. II FSK 3245/15, LEX nr 2431235; Wyrok NSA z dnia 12 lipca 2018 r. II FSK 1946/16, LEX nr 2538086.

28 Szymczak 1981, 398. 
ne. W tej sytuacji skoro z językowego znaczenia pojęcia „sprawozdanie” można wywieść jego treść, to zdaniem NSA zbędna jest argumentacja, że wskazany przepis nie określa szczegółowej formy dokumentowania sprawozdania, czy jego wzoru, a także zbędne są wnioski na rzecz złagodzenia wymogów szczegółowości sprawozdania ${ }^{29}$.

Zdaniem Naczelnego Sądu Administracyjnego należy również pamiętać, że nawet przy braku dostatecznej precyzji uregulowań ustawowych, obowiązkiem podmiotów, których czynności objęte są zakresem hipotezy i dyspozycji norm prawnych, jest troska o rzetelne dokumentowanie prawnie relewantnych zachowań ${ }^{30}$.

\section{SPRAWOZDANIE JAKO DOKUMENT PRYWATNY W POSTĘPOWANIU PODATKOWYM}

Sprawozdanie z przeznaczenia darowizny na kościelną działalność charytatywno-opiekuńcza zdaniem NSA jest dokumentem prywatnym i nie jest objęte domniemaniem prawdziwości przedstawionych w nim oświadczeńn ${ }^{31}$. Dokument taki, na podstawie art. $180 \S 1$ ustawy z dnia 29 sierpnia $1997 \mathrm{r}$. ordynacja podatkowa ${ }^{32}$, może stanowić dowód w postępowaniu podatkowym. Jednak w stosunku do dokumentu prywatnego nie należy posługi-

29 Wyrok NSA z dnia 6 września 2007 r. II FSK 993/06, LEX nr 377575; Wyrok NSA z dnia 22 kwietnia 2008 r. II FSK 312/07, LEX nr 471241; Wyrok NSA z dnia 20 czerwca 2008 r. II FSK 1230/07, LEX nr 472312; Wyrok NSA z dnia 3 listopada 2009 r. II FSK 858/08, LEX nr 588992; Wyrok NSA z dnia 26 stycznia 2010 r. II FSK 545/09, LEX nr 596505; Wyrok NSA z dnia 8 listopada 2011 r. II FSK 891/10, LEX nr 989141; Wyrok NSA z dnia 10 grudnia 2013 r. II FSK 141/12, LEX nr 1529938; Wyrok NSA z dnia 14 lutego 2014 r. II FSK 397/12, LEX nr 1450269; Wyrok NSA z dnia 14 lutego 2014 r. II FSK 396/12, LEX nr 1450268.

30 Wyrok NSA z dnia 23 czerwca 2009 r. II FSK 362/08, LEX nr 513216.

31 Wyrok NSA z dnia 23 marca 2006 r. II FSK 1405/05, LEX nr 261089; Wyrok NSA z dnia 4 stycznia 2007 r. II FSK 588/06, LEX nr 453235; Wyrok NSA z dnia 13 kwietnia 2007 r. II FSK 559/06, LEX nr 927071; Wyrok NSA z dnia 8 stycznia 2008 r. II FSK 1547/06, LEX nr 467823; Wyrok NSA z dnia 4 kwietnia 2008 r. II FSK 231/07, LEX nr 476640; Wyrok NSA z dnia 20 czerwca 2008 r. II FSK 554/07, LEX nr 475544; Wyrok NSA z dnia 17 kwietnia 2009 r. II FSK 7/08, LEX nr 496176.

32 Tekst jedn. Dz. U. z 2019 r., poz. 900 z poźn. zm. 
wać się domniemaniem zgodności z prawdą złożonych w nim oświadczeń, lecz jedynie domniemaniem wyłączającym potrzebę dowodu, że osoba, która dokument podpisała, złożyła w nim oświadczenie. Dokument prywatny nie jest sam przez się dowodem rzeczywistego stanu rzeczy, dlatego wskazane sprawozdanie, powinno zawierać dane na tyle dokładne i konkretne, aby umożliwić podatnikowi samoobliczenie podatku, a następnie organowi podatkowemu w ewentualnym późniejszym postępowaniu podatkowym ustalenie, sprawdzenie, zweryfikowanie danych o przeznaczeniu darowizny na działalność charytatywno-opiekuńczą ${ }^{33}$. Ponieważ sprawozdanie jest dowodem, więc jak każdy dowód w postępowaniu podlega swobodnej ocenie dowodu. Jeżeli organ uzna, że sprawozdanie nie opisuje rzeczywistych zdarzeń, podatnik chcąc skorzystać z prawa do odliczenia, powinien wykazać, że obdarowany przeznaczył świadczenie z tytułu darowizny na cele charytatywno-opiekuńcze ${ }^{34}$.

NSA podkreśla, że sprawozdanie jest dokumentem, który ma istotne znaczenie dla uzyskania uprawnienia do zwolnienia podatkowego przez podatnika, jednak tylko z tego względu, że jego sporządzenie daje takie uprawnienie i że wymóg ten wynika z przepisów podatkowych, nie można mu przypisać cech dokumentu urzędowego w rozumieniu art. $194 \S 2$ ordynacji podatkowej. W postępowaniu podatkowym jest otwarty katalog dowodów i nie ogranicza się jedynie do dokumentów urzędowych ${ }^{35}$.

NSA zauważa, że jeżeli na podstawie danych wynikających z rozważonego sprawozdania kościelnej osoby prawnej, organy podatkowe

33 Wyrok NSA z dnia 23 marca 2006 r. II FSK 1405/05, LEX nr 261089; Wyrok NSA z dnia 4 stycznia 2007 r. II FSK 79/06, LEX nr 927179; Wyrok NSA z dnia 31 stycznia 2007 r. II FSK 199/06, LEX nr 291809; Wyrok NSA z dnia 14 lutego 2007 r. II FSK 262/06, LEX nr 302863; Wyrok NSA z dnia 13 kwietnia 2007 r. II FSK 556/06, LEX nr 927068; Wyrok NSA z dnia 19 lipca 2007 r. II FSK 568/06, LEX nr 400805; Wyrok NSA z dnia 25 października 2007 r. II FSK 1180/06, LEX nr 440475; Wyrok NSA z dnia 22 czerwca 2010 r. II FSK 364/09, LEX nr 643580; Wyrok NSA z dnia 16 grudnia 2011 r. II FSK 1763/10, LEX nr 1112481; Wyrok NSA z dnia 28 marca 2013 r. II FSK 1624/11, LEX nr 1334740; Wyrok NSA z dnia 26 czerwca 2013 r. II FSK 2259/11, LEX nr 1557893; Wyrok NSA z dnia 26 czerwca 2013 r. II FSK 2133/11, LEX nr 1557838; Wyrok NSA z dnia 25 października 2016 r. II FSK 2637/14, LEX nr 2174919.

34 Wyrok NSA z dnia 25 czerwca 2008 r. II FSK 663/07, LEX nr 472269; Wyrok NSA z dnia 25 czerwca 2008 r. II FSK 664/07, LEX nr 485166.

35 Wyrok NSA z dnia 11 lutego 2009 r. II FSK 1575/07, LEX nr 485961. 
w toku postępowania podatkowego nie miały możliwości zweryfikowania, ustalenia i potwierdzenia przeznaczenia darowizny na cel działalności charytatywno-opiekuńczej, to tym bardziej na etapie samoobliczenia podatku takich możliwości nie miał również podatnik. Dysponował on tylko dokumentem prywatnym, informującym, że zawarte w nim oświadczenie złożyła obdarowana przez niego kościelna osoba prawna. Oświadczenie to nie było jednak objęte domniemaniem prawdziwości i zgodności z rzeczywistym stanem faktycznym. Sprawozdanie z rozporządzenia przedmiotem darowizny nie tworzyło podstaw i możliwości do zweryfikowania, ustalenia i potwierdzenia, że sprawozdaje o przeznaczeniu darowizny na kościelną działalność charytatywno-opiekuńczą. W tym stanie rzeczy dokument prywatny nazwany przez jego wystawcę ,sprawozdaniem” w rzeczywistości nie był sprawozdaniem z przeznaczenia darowizny na kościelną działalność charytatywno-opiekuńczą. W szczególności nie dawał dostatecznych podstaw do potwierdzenia przeznaczenia darowizny, a więc nie mógł zgodnie z prawem dawać podstawy do samoobliczenia podatku w celu skorzystania z prawa do wyłączenia darowizny z podstawy opodatkowania podatkiem dochodowym od osób fizycznych na podstawie art. 55 ust. 7 ustawy o stosunku Państwa do Kościoła Katolickiego ${ }^{36}$.

Zdaniem NSA sprawozdanie powinno być tak sporządzone, aby informacje w nim zawarte pozwalały na stwierdzenie, że darowizna została wykorzystana na określony ustawowo cel. Ponadto treść tego dokumentu powinna umożliwić weryfikację zawartych w nim danych. W innym wypadku organ podatkowy może uznać, że przedłożony dokument nie stanowił faktycznie „sprawozdania” i pozbawić podatnika prawa do skorzystania z ulgi podatkowej ${ }^{37}$. Ponadto bez względu na sposób określenia obowiązku sprawozdawczego, dopełnienie go ma umożliwić weryfikację rzeczywistego przeznaczenia darowizny na cele działalności charytatywno-opiekuńczej związku wyznaniowego. NSA ponadto podkreśla, że wykładnia właściwych przepisów ustaw o stosunku Państwa do poszczególnych związków wyznaniowych nie może abstrahować od okoliczności konkretnej sprawy.

36 Wyrok NSA z dnia 23 marca 2006 r. II FSK 1405/05, LEX nr 261089; Wyrok NSA z dnia 8 października 2009 r. II FSK 758/08, LEX nr 550381.

37 Wyrok NSA z dnia 4 stycznia 2007 r. II FSK 79/06, LEX nr 927179. 
Wymagania dotyczące sprawozdania i jego treści zawsze powinny odnosić się do danego stanu faktycznego ${ }^{38}$.

Zgodnie ze stanowiskiem NSA istotą sprawozdania z przeznaczenia darowizny na kościelną działalność charytatywno-opiekuńczą nie jest nieuzasadniony formalizm, ale możliwość skontrolowania, że środki z darowizny zostały rzeczywiście przeznaczone na wskazany ustawowo cel ${ }^{39}$. Skoro ustawodawca określił warunki do odliczenia darowizn na kościelną działalność charytatywno-opiekuńczą, to daje to podstawę do dokonania przez organy podatkowe kontroli i ustalenia, czy dokument ten istnieje, czy ma odpowiednią formę, a także czy darowizna faktycznie została przeznaczona na kościelną działalność charytatywno-opiekuńczą ${ }^{40}$.

Zatem, jeżeli w sprawie przedłożono sprawozdanie, które zostało uznane za zbyt ogólnikowe, ponieważ dowodziło tylko rodzajowego, a nie indywidualnego rozdysponowania darowizn na cele charytatywno-opiekuńcze, to nie może ono być uzupełnione w postępowaniu podatkowym, czy skonkretyzowane poprzez przeprowadzenie dowodu z przesłuchania świadka ${ }^{41}$. Konstrukcja normy prawnej zawartej we właściwych przepisach nie pozwala na konwalidowanie treści wadliwego sprawozdania po upływie dwuletniego okresu, a tym bardziej na zastępowanie po tym czasie sprawozdania innymi środkami dowodowymi ${ }^{42}$.

Regulacja zawarta $\mathrm{w}$ tym przepisie określa zakres postępowania dowodowego, które zobowiązane są przeprowadzić organy podatkowe. Zdaniem NSA organy nie są zobowiązane do zbierania dowodów na okoliczność ustalenia, w jaki sposób zostały rozdysponowane przez obdarowanego środki pochodzące z otrzymanej darowizny. Ta okoliczność ma wynikać ze sprawozdania, które powinno być tak sformułowane, żeby organy podatkowe mogły dokonać weryfikacji danych w nim ujętych. Organ może prowadzić postępowanie dowodowe w zakresie informacji objętych sprawozdaniem w sytuacji, gdy jest ono prawidłowe, czyli zawarte w nim

38 Wyrok NSA z dnia 17 lutego 2011 r. II FSK 1834/09, LEX nr 1070995.

39 Wyrok NSA z dnia 13 kwietnia 2007 r. II FSK 558/06, LEX nr 927070.

40 Wyrok NSA z dnia 13 kwietnia 2007 r. II FSK 559/06, LEX nr 927071.

41 Wyrok NSA z dnia 5 stycznia 2011 r. II FSK 1594/09, LEX nr 952682; Wyrok NSA z dnia 22 stycznia 2013 r. II FSK 1072/11, LEX nr 1288353.

42 Wyrok NSA z dnia 14 lutego 2014 r. II FSK 397/12, LEX nr 1450269; Wyrok NSA z dnia 12 lipca 2018 r. II FSK 1946/16, LEX nr 2538086. 
szczegółowe informacje umożliwiają dokonanie weryfikacji. W takiej sytuacji organ może podejmować czynności wyjaśniające w celu ustalenia czy sprawozdanie odpowiada stanowi rzeczywistemu ${ }^{43}$.

\section{MERYTORYCZNA TREŚĆ SPRAWOZDANIA}

Naczelny Sąd Administracyjny zauważa, że sam fakt otrzymania przez darczyńcę, czyli podatnika, sprawozdania z przeznaczenia darowizny na kościelną działalność charytatywno-opiekuńczą nie uzasadnia zastosowania omawianej ulgi podatkowej, ponieważ jest to uzależnione od jego merytorycznej treści. Inaczej oznaczałoby to, że podstawą analizowanej ulgi byłby tylko, wbrew treści przepisu prawa, udowodniony dokumentem prywatnym fakt złożenia oświadczenia przez kościelną osobę prawną, a nie rzeczywisty, sprawozdany stan rzeczy z przeznaczenia darowizny na działalność charytatywno-opiekuńczą. Taka interpretacja określonych przepisów ustaw określających sytuację prawną poszczególnych związków wyznaniowych regulujących prawo do skorzystania z ulgi podatkowej pozostaje w sprzeczności z celem tych unormowań ${ }^{44}$. Zatem sprawozdanie służy wykazaniu prawa darczyńcy do skorzystania z ulgi podatkowej. W związku z tym powinno zawierać informacje na tyle dokładne, konkretne i sprawdzalne, aby na ich podstawie można było zweryfikować, ustalić i ocenić, iż rzeczywiście darowizna spożytkowana została na działalność charytatywno-opiekuńczą związku wyznaniowego, zgodnie z przepisem prawa ${ }^{45}$.

NSA słusznie podkreśla, że za uzasadniony prawnie należy uznać wymóg złożenia w odpowiednim terminie sprawozdania z wykorzystania podarowanych środków, żeby możliwa była kontrola jego prawdziwości. Ponadto sprawozdanie z przeznaczenia darowizny na kościelną działal-

43 Wyrok NSA z dnia 12 lipca 2018 r. II FSK 1946/16, LEX nr 2538086.

44 Wyrok NSA z dnia 25 października 2007 r. II FSK 1180/06, LEX nr 440475; Wyrok NSA z dnia 25 czerwca 2008 r. II FSK 664/07, LEX nr 485166; Wyrok NSA z dnia 22 czerwca 2010 r. II FSK 364/09, LEX nr 643580.

45 Wyrok NSA z dnia 31 maja 2006 r. II FSK 789/05, LEX nr 282603; Wyrok NSA z dnia 9 sierpnia 2016 r. II FSK 2397/14, LEX nr 2116249; Wyrok NSA z dnia 9 sierpnia 2016 r. II FSK 2049/14, LEX nr 2118972; Wyrok NSA z dnia 31 sierpnia 2017 r. II FSK 2117/15, LEX nr 2344705. 
ność charytatywno-opiekuńczą musi wskazywać, na jaką działalność darowizna została przeznaczona, oraz określać podmiot (osobę), który był jej ostatecznym beneficjentem (konsumentem) ${ }^{46}$. Zdaniem Naczelnego Sądu Administracyjnego w sprawozdaniu nie muszą być natomiast wykazywani beneficjenci pomocy adresowanej do nieokreślonej imiennie grupy osób, czyli realizowanej bezpośrednio przez kościelne osoby prawne. Dotyczy to $\mathrm{np}$. wydawania chleba i innych datków biednym, zapewnienia biednym - w tym bezdomnym - noclegu oraz posiłku w tzw. przytuliskach, prowadzonych w ramach parafii czy też domów zakonnych itp. W takim przypadku istotne znaczenie ma jedynie okoliczność, że w danym okresie kościelna osoba prawna takie działania faktycznie prowadziła oraz że poniosła wydatki na tę działalność ${ }^{47}$.

NSA podkreślił, że sens wprowadzenia tzw. nielimitowanej ulgi podatkowej, wiąże się z określonym spożytkowaniem darowizny przez obdarowaną kościelną osobę prawną. Należy przez to rozumieć jej przekazanie w całości lub części konkretnej osobie w ramach realizowanej działalności charytatywno-opiekuńczej albo też wydatkowanie kwoty darowizny na związane z charytatywno-opiekuńczą aktywnością bezpośrednio podejmowaną przez kościelną osobę prawną, np. na budowę własnego przytuliska dla bezdomnych, zakup artykułów spożywczych rozdawanych następnie nieokreślonym imiennie biednym osobom itp. Zatem zgodnie ze stanowiskiem NSA prawidłowo sporządzone sprawozdanie powinno zawierać na tyle skonkretyzowane informacje, by organ miał możliwość sprawdzenia, jaki podmiot świadczenie z darowizny od kościelnej osoby prawnej otrzymał, albo na jakie zadania wewnętrzne obdarowanego, mieszczące się w działalności charytatywno-opiekuńczej, darowizna została spożytkowana. Tylko w takim przypadku można stwierdzić realizację celu, dla którego omawiana ulga podatkowa została ustanowiona ${ }^{48}$.

46 Wyrok NSA z dnia 8 listopada 2011 r. II FSK 891/10, LEX nr 989141; Wyrok NSA z dnia 28 marca 2013 r. II FSK 1624/11, LEX nr 1334740.

47 Wyrok NSA z dnia 16 października 2009 r., II FSK 849/08, LEX nr 580188; Wyrok NSA z dnia 8 listopada 2011 r. II FSK 891/10, LEX nr 989141; Wyrok NSA z dnia 12 lipca 2016 r. II FSK 1824/14, LEX nr 2101424; Wyrok NSA z dnia 31 sierpnia 2017 r. II FSK 2117/15, LEX nr 2344705.

48 Wyrok NSA z dnia 16 października 2009 r. II FSK 849/08, LEX nr 580188; Wyrok NSA z dnia 25 maja 2011 r. II FSK 67/10, LEX nr 846669; Wyrok NSA z dnia 14 lute- 
Zdaniem Naczelnego Sądu Administracyjnego wskazane cele sprawozdania mogą być osiągnięte, gdy sprawozdanie przedstawiane przez kościelną osobę prawną opisywać będzie na co spożytkowane zostały pieniądze pochodzące z darowizny, ze wskazaniem: wysokości wydatkowanych kwot, dat wydatkowania, rachunków dokumentujących wydatki, osób biorących udział w organizowaniu pomocy charytatywno-opiekuńczej, a także przynajmniej części osób otrzymujących pomoc, tak by można było ustalić, że darowiznę dokonaną przez podatnika przeznaczono na działalność charytatywno-opiekuńczą ${ }^{49}$. Ze sprawozdania powinien wynikać cel, jaki zrealizowano ze środków z darowizny (np. zakup żywności dla ubogich rodzin), czas, w jakim wydatkowano środki, miejsce zakupu żywności, sposób jej rozdzielenia wśród osób potrzebujących, łączna kwota, jaką wydatkowano, a w załączniku do sprawozdania powinny być podane także dane rodzin, którym pomocy takiej udzielono, co pozwoli zweryfikować wiarygodność sprawozdania ${ }^{50}$. NSA podkreślił, że faktyczne wykorzystanie darowizny oznacza ścisły związek środków z niej pochodzących oraz poczynionych wydatków z tych środków na cele wymienione w przepisie prawa ${ }^{51}$.

Samo wskazanie w sprawozdaniu, że darowizna została wykorzystana na pomoc dla dzieci z rodzin ubogich, niepełnych, wielodzietnych, zagrożonych patologiami czy też dotkniętych bezrobociem, dla chorych, rencistów, emerytów, osób starszych, na zapewnienie wypoczynku wakacyjnego, na dofinansowywanie stołówek charytatywnych i pomocy w domach rekolekcyjnych jest zdaniem NSA niewystarczające. Podniesiono, że z tak sporządzonego sprawozdania nie wynikają jakiekolwiek konkretne dane, takie jak formy i daty oraz zasady, na których pomocy tej udzielano, na czym ona polegała, w jakich miejscach się odbywała i jak liczne grupy wymienionych powyżej osób obejmowała, które stołówki czy też domy rekolekcyjne finansowano itp. ${ }^{52}$ Takie dane sprawozdania są na tyle ogól-

go 2014 r. II FSK 397/12, LEX nr 1450269.

49 Wyrok NSA z dnia 10 listopada 2017 r. II FSK 2906/15, LEX nr 2422973; Wyrok NSA z dnia 12 lipca 2018 r. II FSK 1946/16, LEX nr 2538086.

50 Wyrok NSA z dnia 5 grudnia 2017 r. II FSK 2423/15, LEX nr 2437932.

51 Wyrok NSA z dnia 26 czerwca 2013 r. II FSK 2133/11, LEX nr 1557838; Wyrok NSA z dnia 12 lipca 2016 r. II FSK 1824/14, LEX nr 2101424.

52 Wyrok NSA z dnia 23 marca 2006 r. II FSK 1405/05, LEX nr 261089. 
nikowe, że nie można ich zweryfikować bez naruszania interesów czy też prywatności obdarowanych. Ogólnikowość i niedostateczna konkretność sprawozdania uniemożliwiają przeprowadzenie postępowania dowodowego przez organy podatkowe. Brak konkretnych i sprawdzalnych danych o wykorzystaniu tej darowizny uniemożliwia potwierdzenie jej zgodnego z prawem wykorzystania ${ }^{53}$.

NSA zauważa, że z treści właściwych przepisów ustaw o stosunku Państwa do poszczególnych związków wyznaniowych wprost wynika konieczność wykazania celu świadczenia na działalność charytatywno-opiekuńczą kościelnej osoby prawnej ${ }^{54}$. Takie przeznaczenie należy interpretować jako spożytkowanie, wykorzystanie darowizny na wymienioną działalność, której dwuletni okres obejmować może właściwe sprawozdanie ${ }^{55}$.

W uchwale Izby Finansowej z dnia 14 marca 2005 r. (FPS 5/04) Naczelny Sąd Administracyjny stwierdził, że pojęcie ,działalność charytatywno-opiekuńcza” jest pojęciem szerszym niż pojęcie „kościelna działalność charytatywno-opiekuńcza”, a przepis art. 55 ust. 7 ustawy o stosunku Państwa do Kościoła Katolickiego ma charakter szczególny w stosunku do art. 26 ust. 1 pkt 9 lit. b ustawy o podatku dochodowym od osób fizycznych ${ }^{56}$.

Do prowadzenia działalności charytatywno-opiekuńczej powołane zostały osoby prawne Kościoła zgodnie z przepisem art. 38 ust. 1 ustawy o stosunku Państwa do Kościoła Katolickiego oraz podmioty powołane przez władze kościelne zgodnie z art. 38 ust. 2 wskazanego aktu. Ustawa zatem określiła zakres podmiotów uprawnionych do prowadzenia działalności charytatywno-opiekuńczej Kościoła. W tej sytuacji wyłączeniu z podstawy opodatkowania darczyńcy podatkiem dochodowym mogą pod-

53 Wyrok NSA z dnia 23 marca 2006 r. II FSK 1405/05, LEX nr 261089; Wyrok NSA z dnia 14 lutego 2007 r. II FSK 262/06, LEX nr 302863.

54 Wyrok NSA z dnia 31 maja 2005 r. FSK 1808/04, LEX nr 154522.

55 Wyrok NSA z dnia 23 marca 2006 r. II FSK 1405/05, LEX nr 261089; Wyrok NSA z dnia 25 października 2007 r. II FSK 1180/06, LEX nr 440475; Wyrok NSA z dnia 19 lipca 2007 r. II FSK 568/06, LEX nr 400805; Wyrok NSA z dnia 25 maja 2011 r. II FSK 67/10, LEX nr 846669.

56 Wyrok NSA z dnia 31 maja 2005 r. FSK 1808/04, LEX nr 154522; Wyrok NSA z dnia 7 lipca 2005 r. FSK 1995/04, LEX nr 173231; Wyrok NSA z dnia 24 marca 2006 r. II FSK 534/05, LEX nr 231791; Wyrok NSA z dnia 21 kwietnia 2006 r. II FSK 677/05, LEX nr 231467. 
legać darowizny ustanowione na rzecz tak określonych podmiotów. Do grupy tych podmiotów nie może zostać zaliczone stowarzyszenie, ponieważ nie jest jedną z osób prawnych Kościoła, o których mowa w art. 5-14 ustawy o stosunku Państwa do Kościoła Katolickiego w RP ${ }^{57}$.

NSA wielokrotnie w swoich orzeczeniach podkreślał, że przepisy art. 39 i art. 40 ustawy z 17 maja 1989 r. o stosunku Państwa do Kościoła Katolickiego określają co jest lub może być przedmiotem działalności charytatywno-opiekuńczej Kościoła oraz wskazują źródła jej finansowania ${ }^{58}$. Art. 39 wskazanego aktu jest swoistego rodzaju katalogiem form kościelnej działalności charytatywno-opiekuńczej ${ }^{59}$. Słusznie wskazano, że użycie przez ustawodawcę określenia „w szczególności” sprawia, że powyższy katalog nie jest zamknięty. Oznacza to, że również inne działania kościelnych osób prawnych mogą posiadać cechy działalności charytatywno-opiekuńczej. Wyrażenie „działalność charytatywno-opiekuńcza" należy pojmować w sposób szeroki. Za piśmiennictwem ${ }^{60}$ NSA zauważa, że działalność charytatywno-opiekuńcza oznacza działalność polegającą na pomocy ludziom, wspieraniu biednych i potrzebujących oraz troszczeniu się i dbaniu o kogoś ${ }^{61}$. Niewątpliwie w tym pojęciu mieszczą się takie działania, jak organizowanie półkolonii dla biednych dzieci, organizowanie dla nich zajęć kulturalno-rozrywkowych, posiłków, wycieczek, finansowania nagród, finansowanie paczek

57 Wyrok NSA z dnia 19 lipca 2007 r. II FSK 568/06, LEX nr 400805.

58 Analogicznie należy traktować właściwe przepisy ustaw o stosunku Państwa do poszczególnych związków wyznaniowch.

59 Wyrok NSA z dnia 26 stycznia 2010 r. II FSK 545/09, LEX nr 596505; Wyrok NSA z dnia 8 listopada 2011 r. II FSK 891/10, LEX nr 989141; Wyrok NSA z dnia 14 lutego 2014 r. II FSK 397/12, LEX nr 1450269; Wyrok NSA z dnia 14 lutego 2014 r. II FSK 396/12, LEX nr 1450268; Wyrok NSA z dnia 9 sierpnia 2016 r. II FSK 2397/14, LEX nr 2116249; Wyrok NSA z dnia 9 sierpnia 2016 r. II FSK 2049/14, LEX nr 2118972; Wyrok NSA z dnia 31 sierpnia 2017 r. II FSK 2117/15, LEX nr 2344705.

60 Por. Rakoczy, 336-340.

${ }^{61}$ Wyrok NSA z dnia 8 listopada 2011 r. II FSK 891/10, LEX nr 989141; Wyrok NSA z dnia 14 lutego 2014 r. II FSK 397/12, LEX nr 1450269; Wyrok NSA z dnia 14 lutego 2014 r. II FSK 396/12, LEX nr 1450268; Wyrok NSA z dnia 9 sierpnia 2016 r. II FSK 2397/14, LEX nr 2116249; Wyrok NSA z dnia 9 sierpnia 2016 r. II FSK 2049/14, LEX nr 2118972; Wyrok NSA z dnia 31 sierpnia 2017 r. II FSK 2117/15, LEX nr 2344705. 
świątecznych oraz mikołajkowych, organizowanie zajęć świetlicowych, dofinansowanie obiadów dla biednych dzieci w stołówkach szkolnych, wydawanie pieczywa biednym ${ }^{62}$. Ponadto zdaniem NSA w pojęciu kościelnej działalności charytatywno-opiekuńczej mieszczą również się takie działania jak pomoc dla rodzin ofiar katastrofy górniczej, finansowanie leczenia i zakupu leków dla ubogich dzieci, dofinansowanie wypoczynku letniego oraz obozów, wycieczek dzieci i młodzieży, finansowanie zakupu artykułów szkolnych dla dzieci, dożywianie dzieci, pomoc dla matek samotnie wychowujących dzieci, zakup i dystrybucja paczek dla biednych rodzin, pomoc rodzinom dysfunkcyjnym, poszkodowanym przez trąbę powietrzną, a także dla rodzin ofiar katastrof w ruch drogowym i powodzian ${ }^{63}$.

Natomiast zdaniem NSA za taką działalność nie może być uznane krzewienie idei pomocy bliźniemu i postaw społecznych temu sprzyjających ${ }^{64}$. Ponadto za taką działalność nie będzie uznane wykorzystanie darowizny na remont kaplicy. Takie spożytkowanie spełniać będzie wymogi realizacji celów kultu religijnego, a nie działalności charytatywno-opiekuńczej ${ }^{65}$. Za taki cel NSA nie uznał również m.in. remontu i renowacji pomieszczeń klasztornych, odnowienia starodruków, remontu Bazyliki Bożego Ciała. Tego rodzaju działalność pozostaje w związku z realizacją celów kultu religijnego i nie może być utożsamiana z kościelną działalnością charytatywno-opiekuńczą ${ }^{66}$.

62 Wyrok NSA z dnia 8 listopada 2011 r. II FSK 891/10, LEX nr 989141.

63 Wyrok NSA z dnia 31 sierpnia 2017 r. II FSK 2117/15, LEX nr 2344705. Jednakże nie wynika z nich, że działalność gospodarcza przez sam fakt, iż jest prowadzona przez kościelną osobę prawną, staje się działalnością (wyłącznie) charytatywno-opiekuńczą. Wyrok NSA z dnia 27 września 2005 r. FSK 2149/04, LEX nr 177331; Wyrok NSA z dnia 14 lutego 2014 r. II FSK 397/12, LEX nr 1450269; Wyrok NSA z dnia 14 lutego 2014 r. II FSK 396/12, LEX nr 1450268.

${ }^{64}$ Wyrok NSA z dnia 26 stycznia 2010 r. II FSK 1439/08, LEX nr 595780.

65 Wyrok NSA z dnia 26 stycznia 2010 r. II FSK 1439/08, LEX nr 595780.

66 Wyrok NSA z dnia 19 lipca 2007 r. II FSK 568/06, LEX nr 400805. 


\section{PRAWO PODATNIKA DO SKORZYSTANIA Z ULGI PODATKOWEJ}

Prawo do odliczenia wydatków z tytułu darowizny na charytatywno-opiekuńczą działalność kościelnych osób prawnych jest zdaniem NSA prawem podmiotowym podatnika. Dlatego to na nim ciąży obowiązek czuwania nad prawidłowym i wiarygodnym udokumentowaniem zarówno faktu dokonania darowizny, jak i przeznaczeniem jej na cel wskazany w ustawie ${ }^{67}$. Podatnik ma prawo, a nie obowiązek skorzystać z omawianej ulgi podatkowej. Prawo to będzie skuteczne i wywrze pozytywne dla podatnika skutki podatkowe, jeżeli spełnione zostaną wszystkie wymogi przewidziane w prawie podatkowym. Ocena, czy w konkretnym indywidualnym przypadku odliczenie i zadeklarowanie podatku uwzględniające ulgę podatkową spełnia dostatecznie wszystkie wymagane przesłanki prawa podatkowego na etapie samoobliczenia podatku, należy do podatnika. Podatnik samoobliczenia tego dokonuje we własnym imieniu i na swoją odpowiedzialność bez ingerencji organów podatkowych. Przestrzeganie przez podatnika prawa wymaga ustalenia treści, znaczenia i przeznaczenia odpowiednich w relacji do danego samoobliczenia podatku norm prawnych i składających się na nie przepisów w taki sposób, aby czynności rozliczanego okresu podatkowego ocenione zostały prawnie w sposób uzasadniający w pełni wysokości obliczonego i odprowadzonego podatku. W związku z tym, jeżeli podatnik uwzględni w samoobliczeniu ulgę podatkową, która nie spełnia wszystkich wymogów prawa, to musi się liczyć z tym, że jego rozliczenie podatkowe może być zakwestionowane. Bez wpływu na taką ocenę pozostaje fakt, że analizowane przepisy prawa przesłankami niezbędnymi do uznania ulgi po części obarczają kościelną osobę prawną ${ }^{68}$. Inicjatywa dowodowa $\mathrm{w}$ tej sprawie spoczywała na podatniku, który chcąc skorzystać z korzystnego odliczenia, powinien czuwać nad prawidłowym jego udokumentowaniem ${ }^{69}$.

67 Wyrok NSA z dnia 6 września 2007 r. II FSK 993/06, LEX nr 377575.

68 Wyrok NSA z dnia 4 stycznia 2007 r. II FSK 588/06, LEX nr 453235; Wyrok NSA z dnia 31 stycznia 2007 r. II FSK 199/06, LEX nr 291809; Wyrok NSA z dnia 25 czerwca 2008 r. II FSK 664/07, LEX nr 485166.

69 Wyrok NSA z dnia 10 grudnia 2013 r. II FSK 141/12, LEX nr 1529938. 
Ulga podatkowa uregulowana we właściwych przepisach ustaw określających sytuację prawną poszczególnych związków wyznaniowych ma charakter warunkowy. Oznacza to, że uprawnienie podatnika do skorzystania z niej uzależnione jest również od rzeczywistego przeznaczenia darowizny przez obdarowanego na kościelną działalność charytatywno-opiekuńczą, zgodnie z przedstawionym darczyńcy w okresie dwóch lat od otrzymania darowizny sprawozdaniem. Skoro zatem warunkiem konkretyzacji uprawnienia do omawianej ulgi podatkowej jest przeznaczenie środków darowizny na preferowane cele, organy podatkowe dokonując oceny prawa podatnika do skorzystania $z$ tej ulgi, uprawnione są do weryfikowania sposobu realizacji tego celu przez obdarowanego za pomocą dostępnych instrumentów procesowych. Stwierdzenie w toku postępowania podatkowego, że określony w sprawozdaniu cel nie został zrealizowany, skutkować winno wydaniem na podstawie przepisów podatkowych decyzji określającej prawidłową wysokość zobowiązania podatkowego, tj. bez uwzględnienia całości lub części ulgi podatkowej, wykazanej przez podatnika w deklaracji podatkowej ${ }^{70}$.

Należy podkreślić stanowisko NSA, że otwarta pozostaje kwestia, czy w sytuacji, gdy podatnikowi, który został wprowadzony w błąd przez obdarowanego lub gdy obdarowany wadliwie wywiązał się ze swoich obowiązków, co do sposobu przeznaczenia darowizny i w związku z tym podatnik utracił prawo do ulgi podatkowej, uprzednio prawidłowo uwzględnionej w rozliczeniu podatkowym, można przypisać zaległość podatkową z pełnymi konsekwencjami przewidzianymi w przepisach podatkowych. W warunkach, gdy samemu podatnikowi nie można zarzucić niedopełnienia jakichkolwiek obowiązków określonych przepisami, domaganie się zapłaty odsetek w związku z utratą uprawnienia do skorzystania z ulgi podatkowej, należy postrzegać jako swoistą kolizję z zasadą sprawiedliwości ${ }^{71}$.

Jednak NSA zauważa, że sam fakt dokonania darowizny na rzecz kościelnej osoby prawnej nie uzasadnia jeszcze prawa do skorzystania z ulgi podatkowej, uregulowanej we właściwych przepisach. Dla osiągnięcia zamierzonych celów podatkowych trzeba, żeby właściwe sprawozdanie za-

70 Wyrok NSA z dnia 9 sierpnia 2016 r. II FSK 2397/14, LEX nr 2116249; Wyrok NSA z dnia 9 sierpnia 2016 r. II FSK 2049/14, LEX nr 2118972.

71 Wyrok NSA z dnia 9 sierpnia 2016 r. II FSK 2049/14, LEX nr 2118972. 
wierało dane na tyle dokładne i konkretne, aby umożliwić podatnikowi samoobliczenie podatku, a następnie organowi podatkowemu w późniejszym postępowaniu podatkowym ustalenie, sprawdzenie, zweryfikowanie danych o przeznaczeniu darowizny na działalność charytatywno-opiekuńczą ${ }^{72}$. NSA wyprowadza wniosek, że celem wprowadzenia omawianej ulgi podatkowej było wsparcie przez państwo kościelnej działalności charytatywno-opiekuńczej. Dlatego warunkiem powstania prawa do skorzystania z tej ulgi będzie, z jednej strony przekazanie przez podatnika kwoty darowizny na kościelną działalność charytatywno-opiekuńczą, z drugiej - przeznaczenie przez obdarowanego tej darowizny na ten właśnie cel, co potwierdzać powinno złożone sprawozdanie ${ }^{73}$. Sporządzenie stosownego sprawozdania jest obowiązkiem obdarowanego wobec darczyńcy, który ma zatem prawo domagania się, aby było ono rzeczywiste, konkretne i sprawdzalne. Prawo to przysługuje darczyńcy nie tylko dlatego, że jest niezbędne dla skorzystania z ulgi podatkowej, ale również dlatego, że darczyńca ma prawo wiedzieć jak wydatkowano przekazane przez niego środki ${ }^{74}$.

Naczelny Sąd Administracyjny w swoich orzeczeniach wielokrotnie podkreślał, że okoliczność, że z ulgi podatkowej korzysta podatnik, a nie osoba obdarowana nie jest żadnym argumentem, skoro złożenie sprawozdania nie jest i nie może być rozumiane w kategoriach uprawnienia obdarowanego. Złożenie wskazanego sprawozdania jest obowiązkiem prawnym, a podatnik dla zrealizowania tego obowiązku może i powinien wykorzystać instytucję prawną polecenia zgodnie z art. 893 kodeksu cywilnego $^{75}$. Zdaniem NSA złożenie sprawozdania nie jest przy tym ekwi-

72 Wyrok NSA z dnia 8 października 2009 r. II FSK 758/08, LEX nr 550381; wyrok NSA z dnia 16 października 2009 r. II FSK 849/08, LEX nr 580188; Wyrok NSA z dnia 8 listopada 2011 r. II FSK 891/10, LEX nr 989141; Wyrok NSA z dnia 31 maja 2012 r. II FSK 2376/10, LEX nr 1296800.

73 Wyrok NSA z dnia 14 lutego 2014 r. II FSK 397/12, LEX nr 1450269; Wyrok NSA z dnia 14 lutego 2014 r. II FSK 396/12, LEX nr 1450268; Wyrok NSA z dnia 9 sierpnia 2016 r. II FSK 2397/14, LEX nr 2116249; Wyrok NSA z dnia 9 sierpnia 2016 r. II FSK 2049/14, LEX nr 2118972.

74 Wyrok NSA z dnia 31 maja 2006 r. II FSK 789/05, LEX nr 154522; Wyrok NSA z dnia 25 czerwca 2008 r. II FSK 664/07, LEX nr 485166.

75 Ustawa z dnia 23 kwietnia 1964 r. Kodeks cywilny, tekst jedn. Dz. U. z 2019 r., poz. 1145 . 
walentem darowizny, a tylko czynnością o charakterze faktycznym, leżącą w interesie darczyńcy. Darczyńca zgodnie z art. 894 § 1 i 2 k.c. może żądać jego wypełnienia, a po jego śmierci wypełnienia polecenia mogą żądać spadkobiercy. Odmowa wypełnienia polecenia zgodnie z art. $895 \S 2$ k.c. w zw. z art. 405 k.c., rodzi po stronie obdarowanego obowiązek zwrotu przedmiotu darowizny ${ }^{76}$.

Zdaniem NSA obowiązkiem darczyńcy, który chce skorzystać z ulgi podatkowej, jest przedłożenie organom podatkowym sporządzonego przez osobę obdarowaną sprawozdania o wydatkowaniu kwoty darowizny na określony cel, a nie jedynie informacji o tym, że kwota taka została wydatkowana ${ }^{77}$. Zdaniem NSA organy podatkowe nie nakładają na podatnika niewykonalnego obowiązku prawnego, który nie jest przewidziany w przepisach prawa, a niespełnienie żądania złożenia sprawozdania przez osobę trzecią może kształtować sytuację prawną podatnika. Podatnik taki może także uznać, że niezłożenie szczegółowego sprawozdania umożliwiającego mu spełnienie prawa do odliczenia darowizny od podstawy opodatkowania i w konsekwencji narażenie go przez obdarowanego na obowiązek uiszczenia podatku będzie, zgodnie z art. $898 \S 1$ k.c., aktem rażącej niewdzięczności, czego skutkiem może być odwołanie darowizny ${ }^{78}$.

Naczelny Sąd Administracyjny stwierdza ponadto, że nie można powoływać się na wynikający z art. 55 ust. 2 ustawy o stosunku Państwa do Kościoła Katolickiego brak obowiązku kościelnej osoby prawnej prowadzenia dokumentacji wymaganej przez przepisy ustawy ordynacja podatkowa. Jednak obowiązek złożenia sprawozdania jako dokumentu o określonej treści wynika z art. 55 ust. 7 tej ustawy, a także może wynikać z polecenia darczyńcy (art. 893 k.c.), do którego ustawa kościelna nie

76 Wyrok NSA z dnia 6 września 2007 r. II FSK 993/06, LEX nr 377575; Wyrok NSA z dnia 22 kwietnia 2008 r. II FSK 312/07, LEX nr 471241; Wyrok NSA z dnia 3 listopada 2009 r. II FSK 858/08, LEX nr 588992; Wyrok NSA z dnia 8 listopada 2011 r. II FSK 891/10, LEX nr 989141; Wyrok NSA z dnia 14 lutego 2014 r. II FSK 397/12, LEX nr 1450269; Wyrok NSA z dnia 14 lutego 2014 r. II FSK 396/12, LEX nr 1450268.

77 Wyrok NSA z dnia 31 maja 2006 r. II FSK 789/05.

78 Wyrok NSA z dnia 6 września 2007 r. II FSK 993/06, LEX nr 377575; Wyrok NSA z dnia 22 kwietnia 2008 r. II FSK 312/07, LEX nr 471241; Wyrok NSA z dnia 9 sierpnia 2016 r. II FSK 2397/14, LEX nr 2116249; Wyrok NSA z dnia 9 sierpnia 2016 r. II FSK 2049/14, LEX nr 2118972. 
ma zastosowania ${ }^{79}$. Brak po stronie kościelnych osób prawnych prawnego obowiązku prowadzenia dokumentacji dla celów podatkowych, w związku z ich działalnością niegospodarczą (art. 55 ust. 2 ustawy o stosunku Państwa do Kościoła Katolickiego), nie wyłącza również umownego zobowiązania takiej osoby do przedstawienia właściwego rozliczenia sposobu spożytkowania uzyskanej darowizny ${ }^{80}$.

Do poważnej refleksji zmusza posiłkowanie się przez NSA normami prawa wewnętrznego Kościoła Katolickiego dla uzasadnienia obowiązku kościelnych osób prawnych prowadzenia dokumentacji i sporządzania sprawozdań na potrzeby realizacji wymogów określonych w art. 55 ust. 7 ustawy o stosunku Państwa do Kościoła Katolickiego. NSA podkreśla, że wymóg przekazywania przez kościelne osoby prawne sprawozdań darczyńcom został wprowadzony też do prawa wewnętrznego Kościoła Katolickiego. Kan. $1287 \S 2$ Kodeksu Prawa Kanonicznego ${ }^{81}$ przewiduje, iż z dóbr ofiarowanych przez wiernych na rzecz Kościoła zarządcy powinni przedstawiać wiernym odpowiednie sprawozdania, ,według norm, które winno określać prawo partykularne" ${ }^{\text {22 }}$. NSA podniósł również w jednym ze swoich orzeczeń, że obowiązek prowadzenia właściwej dokumentacji wynika z „Informatora”, sporządzonego przez Sekretariat Konferencji Episkopatu Polski w Warszawie dla Księży Biskupów, Kurii Diecezjalnych, Parafii, Caritas, Zgromadzeń Zakonnych, który zawiera wskazówki dotyczące dokumentowania działalności charytatywno-opiekuńczej prowadzonej przez kościelne osoby prawne. Zgodnie z pkt 4 tego dokumentu zaleca się, aby według dyspozycji art. 55 ust. 7 ustawy o stosunku Państwa do

79 Wyrok NSA z dnia 6 września 2007 r. II FSK 993/06, LEX nr 377575; Wyrok NSA z dnia 22 kwietnia 2008 r. II FSK 312/07, LEX nr 471241; Wyrok NSA z dnia 9 sierpnia 2016 r. II FSK 2397/14, LEX nr 2116249; Wyrok NSA z dnia 9 sierpnia 2016 r. II FSK 2049/14, LEX nr 2118972.

80 Wyrok NSA z dnia 14 lutego 2014 r. II FSK 397/12, LEX nr 1450269.

81 Codex Iuris Canonici auctoritate Ioannis Pauli PP. II promulgatus, Acta Apostolicae Sedis 75(1983), s. 1-317; [tekst polski w:] Kodeks Prawa Kanonicznego. 1984. Przekład polski zatwierdzony przez Konferencję Episkopatu tekst dwujęzyczny, Edward Sztafrowski (tłumaczenie) i komisja naukowa pod red. Kazimierza Dynarskiego, Poznań: Pallottinum.

82 Wyrok NSA z dnia 16 października 2009 r. II FSK 849/08, LEX nr 580188; Wyrok NSA z dnia 8 listopada 2011 r. II FSK 891/10, LEX nr 989141; Wyrok NSA z dnia 14 lutego 2014 r. II FSK 396/12, LEX nr 1450268. 
Kościoła Katolickiego, prowadzić dokumentację, która pozwoli na sporządzenie sprawozdania z wykorzystania darowizn ze wskazaniem kwot na konkretne cele charytatywno-opiekuńcze. Taką dokumentacją może być np. zeszyt darowizn ${ }^{83}$. Należy jednak zauważyć, że zgodnie z art. 25 ust. 3 Konstytucji RP związki wyznaniowe są autonomiczne i niezależne ${ }^{84}$.

\section{PODSUMOWANIE}

Wydaje się, że tak liczne orzeczenia NSA potwierdzają zasadność wątpliwości co do wystarczającej jasności i precyzyjności uregulowania zawartego we właściwych przepisach dotyczących ulgi z tytułu dokonania darowizny na kościelną działalność charytatywno-opiekuńczą, zawartych w ustawach regulujących sytuacją prawną poszczególnych związków wyznaniowych. Należy zauważyć, że NSA wiele miejsca w swoich orzeczeniach poświęca wyjaśnianiu właściwego rozumienia pojęcia sprawozdania z przeznaczenia dokonanej darowizny. Jednak widoczny jest brak kompleksowego stanowiska NSA w tej kwestii. Dokonana analiza orzecznictwa NSA pozwala na stwierdzenie, że NSA doprecyzowuje rozumienie tego pojęcia w kolejnych orzeczeniach widząc konieczność kolejnych uszczegółowień. Mimo wielu wyjaśnień, określenia cech i koniecznych elementów sprawozdania $\mathrm{z}$ wykorzystania darowizny na kościelną działalność charytatywno-opiekuńczą, nadal zagadnienie to budzi wiele wątpliwości, a praktyka boryka się z wieloma trudnościami. Są one widoczne po stronie osób obdarowanych, których sprawozdania zdaniem NSA nie są właściwie sporządzone, ale również darczyńców, którzy dokonują złej oceny tych sprawozdań i ponoszą konsekwencje skorzystania z ulgi podatkowej w sposób nieuprawniony.

Wydaje się, że omawiana konstrukcja prawna jest skomplikowana i niewystarczająco precyzyjna. Wywołuje niepokój i zawieszenie po stronie zarówno darczyńcy, ale i osoby obdarowanej. Skorzystanie z ulgi z tytułu dokonania darowizny na kościelną działalność charytatywno-opiekuńczą ma charakter warunkowy. Darczyńca ma trudności w stwierdzeniu, czy

83 Wyrok NSA z dnia 8 października 2009 r. II FSK 758/08, LEX nr 550381.

${ }_{84}$ Zob. Stanisz 2011b, 80-83. 
ma prawo skorzystać ze wskazanej ulgi, ponieważ nie może jednoznacznie stwierdzić, czy sprawozdanie sporządzone przez osobę obdarowaną jest prawidłowe. Natomiast kościelna osoba prawna pozostaje w niepokoju z uwagi na możliwość odwołania uzyskanej przez nią darowizny, jeśli właściwie nie wypełni obowiązku wynikającego w przepisu prawa. Trzeba jednak zauważyć istniejący w doktrynie pogląd, że poszczególne podmioty zobowiązane powinny znać zakres i szczegółowość swojego zobowiązania w sposób niebudzący wątpliwości. Zobowiązanie to powinno wynikać z treści przepisów prawnych, które określają ściśle sytuację prawną adresata. Takie wymaganie wynika z zasady zaufania obywateli do państwa i stanowionego przez nie prawa oraz z zasady bezpieczeństwa prawnego ${ }^{85}$.

Zasadna wydaje się konieczność zadośćuczynienia potrzebom podatnika, czyli darczyńcy oraz samych kościelnych osób prawnych, którym trudno jest prawidłowo sporządzić oraz ocenić sprawozdanie z wykorzystania darowizny na kościelną działalność charytatywno-opiekuńczą. Nasuwa się wniosek, że przepisy ustaw określających sytuację prawną poszczególnych związków wyznaniowych są niewystarczająco precyzyjne, w szczególności w zakresie określenia pojęcia sprawozdania ze spożytkowania środków z tytułu darowizny na kościelną działalność charytatywno-opiekuńczą. Wydaje się, że rozwiązaniem tego problemu mogłaby być odpowiednia nowelizacja właściwych przepisów ustaw regulujących stosunek Państwa do poszczególnych związków wyznaniowych ${ }^{86}$. Dokonane zmiany w przepisach prawa powinny być oparte na szczegółowo określonych cechach i elementach, które precyzyjnie wskazuje w licznym orzecznictwie Na-

85 Zob. orzeczenie TK z dnia 21 czerwca 2011 r. P 26/10, OTK ZU z 2011 r. Nr 5A, poz. 43. Waniek 2018, 211.

${ }^{86}$ Należy podkreślić, że ustawy regulujące stosunek Państwa do poszczególnych związków wyznaniowych mają szczególny charakter. Dotyczące ich działania legislacyjne wymagają zastosowania trybu z art. 25 ust. 5 Konstytucji: „Stosunki między Rzecząpospolitą Polską a innymi kościołami oraz związkami wyznaniowymi określają ustawy uchwalone na podstawie umów zawartych przez Radę Ministrów z ich właściwymi przedstawicielami”. Ich nowelizacja wymaga realizacji konstytucyjnego nakazu dwustronności, czyli możliwości uczestniczenia związków wyznaniowych w procesie uchwalania takich przepisów. Wyklucza to jednostronne działania podejmowane przez ustawodawcę. Dlatego wskazany postulat legislacyjny wymaga wspólnego porozumienia się w tej kwestii pomiędzy stroną rządową a zainteresowanymi związkami wyznaniowymi i wypracowania wspólnego stanowiska. Zob. Stanisz 2011b, 85-88. 
czelny Sąd Administracyjny. Powinno to zlikwidować problemy interpretacyjne przepisów właściwych ustaw określających sytuację prawną poszczególnych związków wyznaniowych oraz ułatwić przeprowadzanie organom podatkowym ewentualnych postępowań wyjaśniających wszystkie wątpliwości dotyczące wskazanych sprawozdań dostarczanych przez podatników do urzędów skarbowych.

\section{BIBLIOGRAFIA}

Abramowicz, Aneta M. 2018. Równouprawnienie związków wyznaniowych w prawie polskim. Lublin: Wydawnictwo KUL.

Borecki, Paweł. 2007. „Zasada równouprawnienia wyznań w prawie polskim”. Studia z Prawa Wyznaniowego 10: 115-160.

Borecki, Paweł. 2015. „Zakaz dyskryminacji ze względu na wyznanie lub światopogląd w prawie polskim". Studia z Prawa Wyznaniowego 18: 135-200.

Czuryk, Małgorzata. 2013. „Źródła finansowania działalności charytatywnej Kościołów i innych związków wyznaniowych". W: Finansowanie kościołów i innych związów wyznaniowych, red. Paweł Sobczyk, Krzysztof Warchałowski, 233-250. Warszawa: Oficyna Wydawnicza ASPRA-JR.

Koredczuk, Józef. 2013. „Ulgi podatkowe z tytułu darowizn jako źródło finansowania Kościołów i innych związków wyznaniowych oraz ich działalności”. W: Finansowanie kościołów i innych zwiazków wyznaniowych, red. Paweł Sobczyk, Krzysztof Warchałowski, 265-276. Warszawa: Oficyna Wydawnicza ASPRA-JR.

Maruszak, Grażyna. 2011. „Darowizny na kościelną działalność charytatywno-opiekuńczą w podatku dochodowym od osób fizycznych". Roczniki Nauk Prawnych 2: 161-172.

Misztal, Henryk, Piotr Stanisz. 2009. „Włoski model finansowania związków wyznaniowych". W: Pro bono Reipublicae. Ksiega jubileuszowa Profesora Michała Pietrzaka, red. Paweł Borecki, Andrzej Czohara, Tadeusz J. Zieliński, 351-353. Warszawa: Wydawnictwo LexisNexis.

Ners, Krzysztof J. 2000. „Zasady finansowania instytucji kościelnych w Polsce. Problematyka w aspekcie de lege lata i de lege ferenda". W: Systemy finansowania instytucji kościelnych w Europie. Materiat Międzynarodowej Konferencji, Sandomierz, 13-14 września 1999 r., red. Józef Krukowski, 133-147. Lublin: Wydawnictwo KUL. 
Pieron, Bartłomiej. 2011. „Finansowanie celów kultu religijnego realizowanego przez kościoły i inne związki wyznaniowe". Studia z Prawa Wyznaniowego 14: $141-159$.

Pietrzak, Michał. 2010. Prawo wyznaniowe. Warszawa: Wydawnictwo LexisNexis. Rakoczy, Bartosz. 2008. Ustawa o stosunku Państwa do Kościoła Katolickiego w Rzeczypospolitej Polskiej. Komentarz. Warszawa: Oficyna a Wolters Kluwer business.

Schanda, Balázs. 2003. „Finansowanie Kościołów w Europie”. W: Kultura i prawo. Religia $i$ wolność religijna w Unii Europejskiej, red. Józef Krukowski, Otto Theisen, 207-215. Lublin: Wydawnictwo KUL.

Skorupka, Stanisław, Halina Auderska, Zofia Łempicka (red.). 1968. Mały Słownik Języka Polskiego. Warszawa: PWN.

Stanisławski, Tadeusz. 2001. „Darowizny na kościelną działalność charytatywno-opiekuńczą". Studia z Prawa Wyznaniowego 2: 81-91.

Stanisławski, Tadeusz. 2003. „Podatek kościelny czy darowizna na utrzymanie Kościoła?" Studia z Prawa Wyznaniowego 6: 175-182.

Stanisławski, Tadeusz. 2004. „Nowe regulacje dotyczące darowizn na cele kościelne". Studia z Prawa Wyznaniowego 7: 209-220.

Stanisławski, Tadeusz. 2009. „Darowizny na cele kultu religijnego i kościelną działalność charytatywno-opiekuńczą. Kontrowersje i nowe rozwiązania”. Studia z Prawa Wyznaniowego 12: 329-340.

Stanisławski, Tadeusz. 2011. Finansowanie instytucji wyznaniowych ze środków publicznych w Polsce. Lublin: Wydawnictwo KUL.

Stanisz, Piotr. 2009. „Perspektywy zmiany systemu finansowania kościołów i innych związków wyznaniowych w Polsce". Studia z Prawa Wyznaniowego 12: 5-34.

Stanisz, Piotr. 2011a. „Finansowe i majątkowe aspekty działalności kościołów i innych związków wyznaniowych". W: Artur Mezglewski, Henryk Misztal, Piotr Stanisz, Prawo wyznaniowe. 237-273. Warszawa: Wydawnictwo C.H. Beck.

Stanisz, Piotr. 2011b. „Naczelne zasady instytucjonalnych relacji państwo-kościół”. W: Artur Mezglewski, Henryk Misztal, Piotr Stanisz, Prawo wyznaniowe. 74-88. Warszawa: Wydawnictwo C.H. Beck.

Stanisz, Piotr. 2012. „Zwolnienia i ulgi podatkowe jako forma finansowania związków wyznaniowych ze środków publicznych". W: Finansowanie związków wyznaniowych $w$ krajach niemieckojęzycznych $i$ w Polsce. Die Finanzierung der Religionsgemeinschaften in der Deutschsprachigen Ländern und in Polen, red. Dariusz Walencik, Marcin Worbs. 161-169. Opole: Redakcja Wydawnictw Wydziału Teologicznego Uniwersytetu Opolskiego.

Stanisz, Piotr. 2017. Religion and Law in Poland, Kluwer Law International. 
Szymczak, Mieczysław (red.). 1981. Słownik Języka Polskiego, t. III. Warszawa: PWN.

Walencik, Dariusz. 2004. „Nabywanie dóbr doczesnych przez osoby prawne Kościoła katolickiego w świetle prawa polskiego i prawa kanonicznego". Studia z Prawa Wyznaniowego 7: 157-179.

Walencik, Dariusz. 2007. „Wpłaty 1\% podatku jako sposób refinansowania pomocy społecznej". W: Funkcje publiczne związów wyznaniowych. Materiały III Ogólnopolskiego Sympozjum Prawa Wyznaniowego (Kazimierz Dolny, 16-18 maja 2006), red. Artur Mezglewski, 237-270. Lublin: Wydawnictwo KUL.

Walencik, Dariusz. 2009a. „Ewolucja procedury alokacji 1\% podatku na rzecz organizacji pożytku publicznego". Przegląd Prawa Wyznaniowego 1: 9-26.

Walencik, Dariusz. 2009b. „Wpłaty 1\% podatku dochodowego od osób fizycznych jako źródło finansowania działalności instytucji kościelnych". Studia z Prawa Wyznaniowego 12: 311-328.

Walencik, Dariusz. 2010. „Darowizny na działalność charytatywno-opiekuńczą kościelnych osób prawnych”. Studia z Prawa Wyznaniowego 13: 261-277.

Walencik, Dariusz. 2012. „Dobrowolna ofiarność wiernych. Podstawy prawne i rozwiązania praktyczne". W: Finansowanie zwiazków wyznaniowych w krajach niemieckojęzycznych $i w$ Polsce. Die Finanzierung der Religionsgemeinschaften in der Deutschsprachigen Ländern und in Polen, red. Dariusz Walencik, Marcin Worbs, 93-109. Opole: Redakcja Wydawnictw Wydziału Teologicznego Uniwersytetu Opolskiego.

Waniek, Danuta. 2018. „Glosa do wyroku Naczelnego Sądu Administracyjnego z dnia 8 listopada 2016 r. (sygn. akt II FSK 2768/14)". Przeglad Sejmowy 1: $209-220$

Zieliński, Tadeusz. 2012. „Art. 27”. W: Andrzej Czohara, Tadeusz J. Zieliński. Ustawa o stosunku państwa do gmin wyznaniowych żydowskich w Polsce. Komentarz. 171-173. Warszawa: Wolters Kluwer business.

\section{TAX RELIEFS FOR DONATIONS TO CHURCH CHARITY AND WELFARE ACTIVITIES}

\section{Summary}

Religious organizations in Poland can be financed through donations. The donor may benefit from a tax relief for making a donation. In a special way, the donor may benefit from a tax relief for making a donation for church charity and welfare activities conducted by church legal entities. The normative basis for this kind of 
tax reliefs are the laws on the relation between the state and individual religious organizations, and not tax laws. However, according to the provisions, several conditions have to be fulfilled for the tax relief in question to be claimed. A church legal entity to which a donation has been made shall issue a receipt to the donor and shall submit a report on the use of the donation for charitable and protective purposes within two years of receiving a donation. In addition, according to the tax regulations, the amount of a donation should be confirmed by a relevant bank statement. In practice, the fulfilment of these conditions gives rise to many difficulties. This is evidenced by the rich case law of the Supreme Administrative Court, especially regarding the question of a report on spending a given donation on church charity and welfare activities.

The case law of Supreme Administrative Court clarifies the concept of the report under discussion. However, as the practice has shown, it seems that these explanations are still insufficient.

Key words: tax relief; donation; church charity and welfare activities; Supreme Administrative Court; church legal entity; case law of the Supreme Administrative Court

Ttumaczenie własne autora 